\title{
Hazards of excessive use of bark mulch in green areas
}

\author{
Szymon Lukasiewicz \\ Botanical Garden, Adam Mickiewicz University, Dąbrowskiego 165 60-594 Poznań, Poland \\ e-mail: Szymon.Lukasiewicz@amu.edu.pl
}

\begin{abstract}
Bark mulch has been a popular additive in production and preparation of traditional garden soils. Being a porous material, it improves soil structure and ventilation. It has also become a valuable component of substrates, particularly for coniferous plants. Recently bark mulching of large areas has become increasingly common. The volume of bark mulch used for such purposes is very large. Bark is characterised by for high content of e.g. heavy metals, such as manganese, aluminum, zinc, cadmium or lead. After mineralization, elements introduced to soil will change its chemical composition, thus distorting the original balance of elements. This could lead to successive accumulation of those elements ( $\mathrm{Mn}, \mathrm{Cd}, \mathrm{Al}, \mathrm{Zn}, \mathrm{Pb})$ in soil, up to toxic levels.
\end{abstract}

Key words: woody plants, bark, mulching, heavy metals.

\section{Introduction}

Until the middle of the $20^{\text {th }}$ century, bark (constituting up to $20 \%$ of logs' mass) had been a problematic waste material originating from wood processing. As a by-product of sawmills and wood processors, most of it was simply incinerated. Due to the difficulties related to its disposal and the nuisance caused by it, numerous applications of bark were developed, such as manufacturing of cork insulation boards or an additive used in chipboard manufacturing. After grinding, bark fines and dust are used to replace wood flour as fillers in manufacturing of plastics and linoleum, or as cleaning and filtering agents. Fines obtained from pure bark (without wood) are combined with chemicals and used for manufacturing floor cladding, rubber products, glue, porous bricks and also as a carrier of insecticidal dusts. In Scandinavia, bark mats of a thickness of $0.4 \mathrm{~m}$ are used as a layer separating road surfaces from freezing subgrades (Prosiński 1984; Faber 1959, after: Surmiński 1996). Bark is characterized by high porosity (up to $85 \%$ ), low water holding capacity and small bulk density (260-370 $\left.\mathrm{g} \cdot \mathrm{dm}^{-3}\right)$ - bark is typically five times lighter than mineral soil of average density of approx. $1500 \mathrm{~g} \times \mathrm{dm}^{-3}$ (Komosa 2010).

\section{Properties and functions of bark}

Outer bark, or simply bark, is the external layer of trunks of woody plants. It protects the deeper layers of live tissues against mechanical damage, pathogens and temperature changes.

Being a form of "clothing" for the plant, bark must provide safe protection against potential aggressors and pathogens. Therefore, it has low permeability for water and air, thus providing a barrier against easy penetration of microorganisms (bacteria, viruses and fungi) and against water losses from outside the trunk. It also provides efficient thermal insulation due to a low heat conduction rate. As far as animals are concerned (e.g. beetles and their larvae biting into tree trunks and feeding on wood), plants had to develop a more sophisticated safeguard. This is why the chemical composition of bark differs from that of wood. It consists of substances and compounds such as glycosides, alkaloids, waxes, resins, phenol compounds (e.g. tannins), etc. It should be remembered that numerous resinous and phenolic substances inhibit the growth and development of plants. They can be washed away by rainwater if bark is deposited in one place over a long period of time (Prosiński 


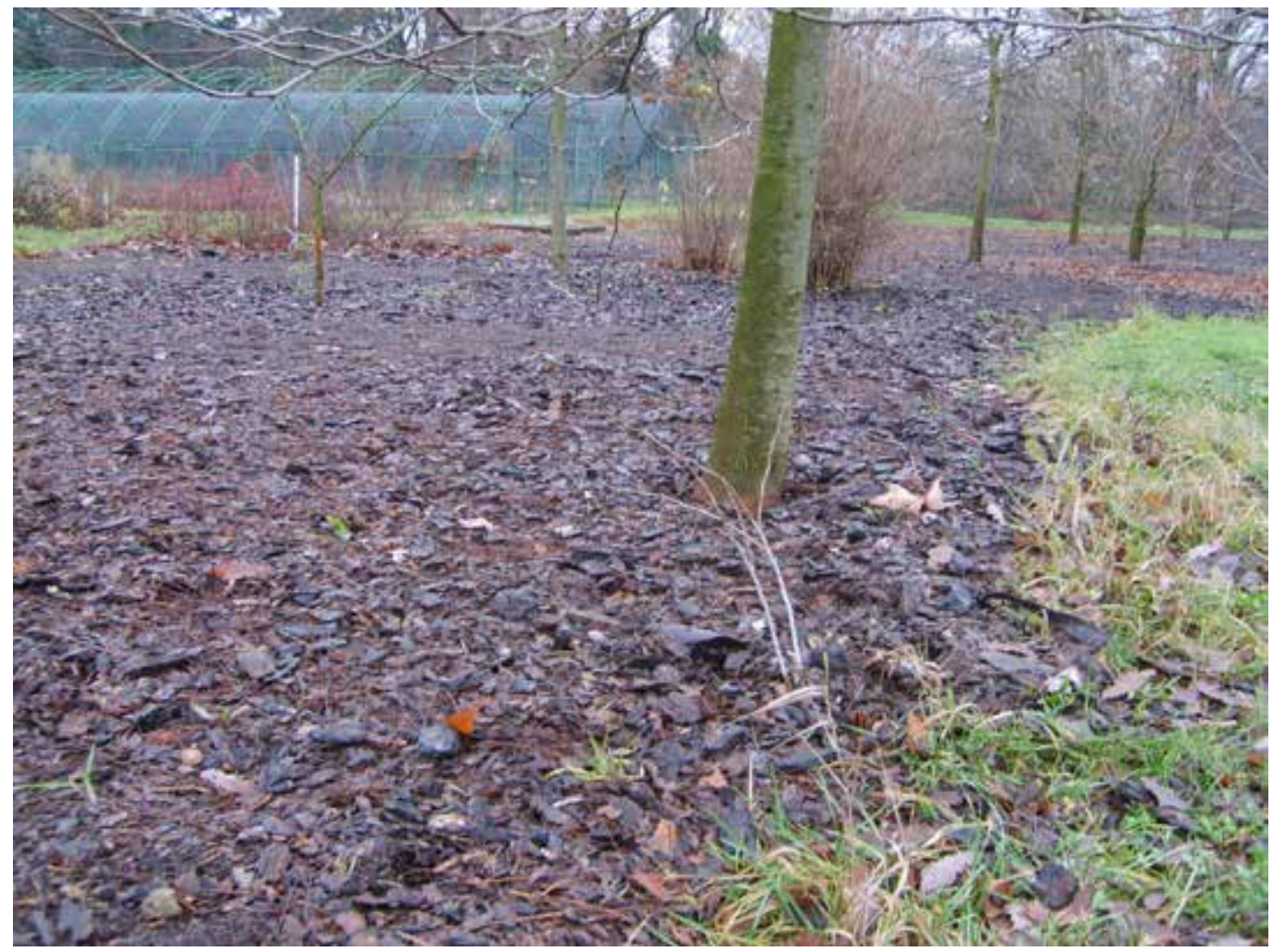

Figure 1. Applying thick layers of bark mulch over large areas should be avoided

1984; Faber 1959; Haber 1976, quoted in: Surmiński 1996; Lewak \& Kopcewicz 2009).

In the course of evolution of woody plants, the above-described chemism of bark became the process that made their survival possible. It gave bark a bitter and unattractive taste, thus making it inedible. It should be emphasized that concentrations of certain elements accumulated in bark are so high that in field or compost soil they would be considered toxic. In particular, this applies to concentrations of such elements as manganese and heavy metals: cadmium, zinc, lead or aluminum.

\section{Material and methods}

In 2011, analyses of the content of total forms (P, K, Ca, $\mathrm{Mg}, \mathrm{Fe}, \mathrm{Mn}, \mathrm{Cu}, \mathrm{Zn}, \mathrm{B}, \mathrm{Al}, \mathrm{Co}, \mathrm{Na}, \mathrm{Pb}$ and $\mathrm{Cd}$ ) in commercially available pine bark from the region of Pomerania (northern Poland) were carried out. The said bark was mulched over two test yards in the Botanical Garden of Adam Mickiewicz University (Fig. 1). Mineralisation was performed for $30 \mathrm{~min}$ at $210^{\circ} \mathrm{C}$, using a mixture of the following acids: $37 \% \mathrm{HCl}$ : $65 \% \mathrm{HNO} 3(3: 1)$.

The analyses were made at the laboratory of the Dendrology Institute of the Polish Academy of Sciences in Kórnik near Poznań. Content of elements was analyzed using ICP-TOF-MS (Time Of Flight Mass Spectrometry) method by means of a GBC spectrometer (OptiMass 9500).

\section{Results and discussion}

On the basis of the results of the analyses (Table 1 OB '2010), elevated concentrations of lead, manganese and aluminum were identified. Namely, lead concentration at a level of $36-55 \mathrm{mg} \mathrm{kg}^{-1}$ exceeded the geochemical background in soils for Poland $\left(18 \mathrm{mg} \mathrm{kg}^{-1}\right)$. In the case of manganese, nutritional requirements of plants are satisfied with total forms of this particular element in plants at a level of $10-25 \mathrm{mg} \mathrm{kg}^{-1}$ The results of analyses, ranging from 250 to over $500 \mathrm{mg} \mathrm{kg}^{-1}$, denote its elevated, potentially toxic impact on soil and plants. The content of aluminum (over $12600 \mathrm{mg} \mathrm{kg}^{-1}$ ) is several hundred times greater than the level found in plants $\mathrm{X} 0$ X00 $\mathrm{mg} \mathrm{kg}^{-1}$, Table 1 and 2 (Kabata-Pendias \& Pendias 1999; Mąderek 2011).

As reported in the literature, among heavy metals also other elements can build up high concentrations in bark, namely: cadmium (8.7-12 $\mathrm{mg} \mathrm{kg}^{-1}$ in dry matter) and zinc (1700-2200 mg kg-1 in dry matter) (Kwidzyn, Energopomiar, Institute of Soil Science and Plant Cultivation in Puławy, quoted in: Siuta \& Żukowski 2008) Table 1-3. The 
Table 1. Comparison of average concentration of selected heavy metals in Polish soils to admissible concentrations (in $\mathrm{mg} \mathrm{kg}^{-1}$ ) of the same elements in farm soils, fertilizers, and pine bark. Explanations: OB 2010 - Botanical Garden, non published data; Siuta 2008 - literature data, the number after \pm indicates standard deviation

\begin{tabular}{|c|c|c|c|c|c|}
\hline \multirow{2}{*}{$\begin{array}{l}\overrightarrow{0} \\
\stackrel{0}{0} \\
\overrightarrow{I I}\end{array}$} & \multicolumn{2}{|c|}{ Soil } & \multirow[t]{2}{*}{ Fertilizers } & \multicolumn{2}{|c|}{ Bark } \\
\hline & 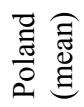 & 䏤 & & ต & 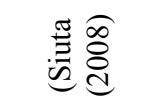 \\
\hline $\mathbf{P b}$ & 18 & $<50$ & $<100$ & $36 \pm 12$ & - \\
\hline Cd & 0.2 & $<3$ & $<3$ & $\mathbf{0 . 7 4} \pm 0.32$ & $8.7-12$ \\
\hline Mn & 240 & $<250$ & - & $\mathbf{4 0 8} \pm 122$ & $450-680$ \\
\hline Zn & 40 & $<300$ & $<1500$ & $\mathbf{1 2 4} \pm 42$ & $1700-2200$ \\
\hline
\end{tabular}

Table 2. Examples of aluminum concentration in edible plants compared to pine bark concentration (source: Gworek 2006)

\begin{tabular}{|c|c|}
\hline \multicolumn{2}{|c|}{$\mathrm{Al}\left[\mathrm{mg} \cdot \mathrm{kg}^{-1}\right]$} \\
\hline Bean grains & 1 \\
\hline Cereal grains & 5 \\
\hline Beets & 6 \\
\hline Potatoes & 76 \\
\hline Spinach & $96-104$ \\
\hline Rhubarb & 166 \\
\hline Wheat (leafs) & $70-230$ \\
\hline Pine bark & $\mathbf{6 7 5 6} \pm 3051$ \\
\hline
\end{tabular}

mentioned values are four and nearly two (respectively) times greater than the maximum allowed concentrations ( $3 \mathrm{mg} \mathrm{kg}^{-1}$ for cadmium and $1500 \mathrm{mg} \mathrm{kg}^{-1}$ for zinc: Kowalik 2001; Regulation 2004 quoted in: Jędrczak 2007).

The above data demonstrate a defective chemical composition of bark. Due to its gradual mineralization, release and transfer of the said elements to soil, large amounts of bark should not be used for mulching green areas of considerable thickness.

Bark mulch has been a popular additive in the production and preparation of traditional garden soils. Being a porous material, it improves soil structure and aeration. It has also become a valuable component of substrates, particularly for coniferous plants. Due to the intensity of nursery production and short production cycle of plants, the presence of barks near plant roots in containers and pots does not lead to noticeable, negative impacts on plants' development. Namely, the time required to grow a plant and to transplant it to soil is too short for bark decomposition and release of elements. Due to bark's low weight, substrates consisting of mineral soil, peat and bark mixed by volume (e.g. $1: 0.5: 0.2$ ) contain a marginal amount of bark measured by weight. In the case of plants sold in containers, the mulching layer of bark is usually thin.

Recently bark mulching of large areas has become increasingly common. The volume of bark mulch used for such purposes is very large (Fig. 1). While for aesthetic purposes it is enough to spread a thin layer of bark on the topsoil, practical purposes (reduced evaporation, inhibiting weed growth, improved topsoil structure, etc.) require a thicker layer of 5 to $10 \mathrm{~cm}$ (Oleksyn et al. 2007). At this thickness, the overall volume of bark used is very large. The amount of elements (such as manganese, aluminum, zinc, cadmium or lead) introduced to soil in the process of

Table 3. Mean concentrations of elements in pine bark as compared to mean concentrations in leafs of selected wood trees. The last column shows the concentration of a given element in bark compared to its concentration in plant material (data in $\mathrm{mg}$ $\mathrm{kg}^{-1} \pm$ standard deviation). Explanations: OB2010 - Botanical Garden of Adam Mickiewicz University, non published data; Siuta (2008) - literature data

\begin{tabular}{|c|c|c|c|c|c|c|c|c|c|c|c|c|c|c|c|c|c|c|}
\hline \multirow[b]{2}{*}{ 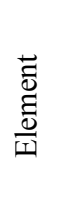 } & \multicolumn{15}{|c|}{ Leafs (species) } & \multicolumn{2}{|c|}{ Bark } & \multirow[b]{2}{*}{$\begin{array}{l}\text { Bark/ } \\
\text { Leafs }\end{array}$} \\
\hline & $\stackrel{\bar{d}}{\stackrel{d}{*}}$ & 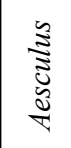 & 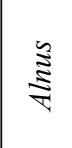 & 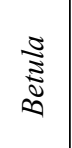 & 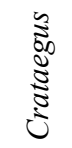 & $\begin{array}{c}3 \\
8 \\
8 \\
5\end{array}$ & 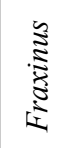 & $\frac{\mathfrak{z}}{\stackrel{\Xi}{\Xi}}$ & 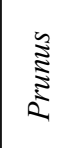 &  & 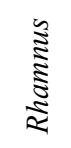 & 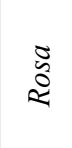 & $\stackrel{\vec{\Xi}}{\tilde{\Xi}}$ & $\stackrel{\Xi}{\stackrel{\Xi}{*}}$ & $\underset{\mathfrak{\Xi}}{\vdots}$ & 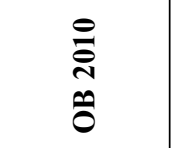 & 焉 & \\
\hline $\mathbf{P b}$ & 0.35 & 2.50 & - & 2.60 & 0.42 & 3.20 & 0.70 & 1.60 & 0.34 & 1.70 & 0.52 & 0.20 & - & 1.50 & - & $36 \pm 12$ & - & $\mathrm{X} 0$ \\
\hline Cd & 0.15 & 0.20 & - & 0.25 & 0.10 & 0.06 & 0.02 & 2.35 & 0.10 & 0.07 & 0.10 & 0.10 & - & 0.01 & - & $\mathbf{0 . 7 4} \pm 0.32$ & $8.7-12$ & $\mathrm{X}-\mathrm{X} 00$ \\
\hline Mn & 123 & 90.5 & 348 & 817 & 26.9 & 2041 & 52.0 & 161 & 40.5 & 1032 & 44.3 & 44.3 & 502 & 232 & 179 & $\mathbf{4 0 8} \pm 122$ & $450-680$ & $\mathrm{X}-\mathrm{X} 0$ \\
\hline $\mathbf{Z n}$ & 41.6 & 13.2 & 36.3 & 164 & 16.7 & 36.7 & 27.6 & 165 & 12.6 & 34.6 & 10.4 & 9.25 & 111 & 21.7 & 30.0 & $124 \pm 42$ & $1700-2200$ & $\mathrm{X} 0-\mathrm{X} 00$ \\
\hline Al & 34.5 & 77.9 & - & - & 35.0 & - & - & - & 25.5 & - & 50.6 & 21.0 & - & - & - & $6756 \pm 3051$ & - & X00 \\
\hline
\end{tabular}


mineralization can change the chemical composition of the substrate, thus distorting the original balance of elements. If the above procedure is regularly repeated, it can lead do negative changes in the soil environment, caused by the increase in the levels of only some of its components: Mn, $\mathrm{Cd}, \mathrm{Al}, \mathrm{Zn}, \mathrm{Pb}$. In such a case, those elements can build up high concentrations, up to toxic levels. Therefore, mass bark mulching of soil over larger areas (e.g. corresponding to tree crown size) can only be done sporadically, once in many years.

To a lesser degree the above applies to such species as blueberry, as they are immune to high soil manganese levels. Nonetheless, soil fertilization with bark in blueberry plantations is an exception rather than the rule (not unlike the use of sodium by tobacco growers, as tobacco is a sodium-loving plant, contrary to most other plants, negatively affected by excessive amounts of sodium).

According to the literature data, layers of bark mulch should be enriched with nitrogen fertilizers to decompose and neutralize potentially toxic compounds, such as phenol compounds (e.g. tannins, waxes or resins) and to restore the $\mathrm{C}: \mathrm{N}$ ratio. While in soil substrates the correct $\mathrm{C}: \mathrm{N}$ ratio values are considered to be $20-40: 1$, the same proportion in bark is $120-200$ to $300-500$ (Siuta 2002; Siuta \& Żukowski 2008). Under such circumstances, nitrogen fertilizers increase the decomposition rate of bark, prevent temporary immobilization of nitrogen in soil captured by microorganisms and support neutralization of the said substances, potentially toxic to plants. A deficit of $\mathrm{N}$, given such a wide proportion, is a factor limiting the decomposition, as $50 \%$ of the mass of microorganisms that participate in the biodegradation of organic matter is constituted by nitrogen taken from the substrate (Boratyński 1981; Komosa 2010; Siuta 2002). According to Siewniak (1996), the recommended total dose is $1.5-2.0 \mathrm{~kg}$ of ammonium nitrate $(\mathrm{V})$ (or another nitrogen fertilizer) per $1 \mathrm{~m}^{3}$ of bark.

Commercially available 80-liter bags of bark curls are a by-product of the bark stripping technology. Bark is removed from tree trunks by means of mechanical strippers, or hydraulic strippers involving the use of pressurized hot water (Komosa 2010). In the case of the latter, the resulting bark curls are dried and become brownish and light weight. In macroscopic terms, composted bark mass should have another appearance. Such "untouched" appearance may indicate that the minimum 12 months of composting, as recommended in the literature, did not take place. If such material is used on an uncontrolled scale, it may negatively affect substrates and plants.

\section{References}

Boratyński K., 1981, Chemia rolna [Farming Chemistry], PWRiL, Warszawa.

Gworek B., 2006, Glin w środowisku przyrodniczym a jego toksyczność [Aluminum in Natural Environments and its Toxicity], Ochrona Środowiska i Zasobów Naturalnych 29: 27-38.

Jędrczak A., 2007, Biologiczne przetwarzanie odpadów [Biological Processing of Waste] Wydawnictwo Naukowe PWN, Warszawa.

Kabata-Pendias A. \& Pendias H., 1999, Biogeochemia pierwiastków śladowych [Biogeochemistry of Trace Elements], Wydawnictwo Naukowe PWN, Warszawa.

Komosa A., 2010, Dane niepublikowane [Unpublished data].

Kowalik P., 2001, Ochrona środowiska glebowego [Protection of Soil Environment], Wydawnictwo Naukowe PWN, Warszawa.

Lewak S. \& Kopcewicz J., 2009, Fizjologia roślin. Wprowadzenie [Physiology of Plants. Introduction], Wydawnictwo Naukowe PWN, Warszawa.

Mąderek E., 2011, Wyniki analiz materiału roślinnego [Results of Plant Material Analyses] (manuscript), Institute of Dendrology, Polish Academy of Sciences, Kórnik.

Oleksyn J., Kloeppel B. D., Łukasiewicz Sz., Karolewski P. \& Reich P. B., 2007, Ecophysology of horse chestnut (Aesculus hippocastanum L.) in degraded and restored urban sites, Polish Journal of Ecology 55(2): 245-260.

Prosiński S., 1984, Chemia drewna [Chemistry of Wood], PWRiL, Warszawa.

Regulation of the Minister of Agriculture and Rural Development of 19 October 2004 on enforcing certain provisions of the Fertilizers Act (Journal of Laws No. 236, item 2369). [quoted in: Jędrczak A., 2007].

Siewniak M., 1996, Konieczność i możliwości kompensacji warunków siedliskowych drzew ulicznych [Compensation of Habitat Conditions for Street Trees. Needs and Possibilities], [in:] Zieleń Warszawy. Problemy, nadzieje. Materiały konferencji naukowo-technicznej [Warsaw's Green Areas. Problems, Hopes. Conference Proceedings], September 6, 1996, Warszawa-Powsin: 93-105.

Siuta J., 2002, Przyrodnicze użytkowanie odpadów [Natural Ways of Reusing Waste], Instytut Ochrony Środowiska, Warszawa.

Siuta J. \& Żukowski B., 2008, Degradacja i rekultywacja powierzchni ziemi w Polsce [Degradation and Reclamation of Land Surface in Poland], Instytut Ochrony Środowiska, Warszawa.

Surmiński J., 1996, Kora. Budowa anatomiczna, skład chemiczny, możliwości wykorzystania [Bark. Anatomy, Chemical Composition, Applications], Wydawnictwo Akademii Rolniczej, Poznań. 